\title{
Settlement Prediction of a Group of Lightweight Aggregate (LECA) Columns Using Finite Element Modelling
}

\author{
Azhani Zukri $^{1}$ *, Ramli Nazir ${ }^{2}$, Ng Kok Shien ${ }^{3}$ \\ ${ }^{1}$ Fakulti Kejuruteraan Awam \& Sumber Alam, Universiti Malaysia Pahang, Lebuhraya Tun Razak, Gambang, Pahang, Malaysia \\ ${ }^{2}$ Centre of Tropical Geoengineering, Fakulti Kejuruteraan Awam, Universiti Teknologi Malaysia, Skudai, Johor, Malaysia \\ ${ }^{3}$ Fakulti Kejuruteraan Awam, Universiti Teknologi Mara, Cawangan Pulau Pinang, Seberang Perai, Pulau Pinang, Malaysia \\ *Corresponding author E-mail: engr.azhani@gmail.com
}

\begin{abstract}
The method of reinforcing the soft clays with stone columns is the most commonly adopted technique to enhance its load carrying capacity and to reduce settlements. Their performance with respect to bearing capacity is well researched, but the understanding of settlement characteristics still requires extensive investigations. Moreover, no studies have been made to explore the effectiveness of stone columns using Lightweight Expanded Clay Aggregate (LECA) as filler material replacing normal stone/aggregates in order to improve settlement behavior of soft clay. LECA is known as a common lightweight material that have been applied successfully in civil engineering works where weight is an issue because the materials can help to reduce dead loads and lateral forces by more than half in installations over structures and those with soft soils. The purpose of this work is to assess the suitability of reinforcing technique by LECA columns to improve the settlement through finite element. The analysis of performance of LECA column in soft soil improvement was conducted through finite elements methods by using Plaxis 3D commercial software. Based on the results the settlement ratio was reduced as the column length increased until unity at end bearing condition where $\beta=1.0$. It is also observed that bulging was reduced with closer spacing between LECA columns.
\end{abstract}

Keywords: Lightweight Expanded Clay Aggregate, Settlement, Stone column, Finite element, Soft Soil improvement.

\section{Introduction}

Construction of highway embankments using conventional design methods such as precompression, preloading and PVD, dredging, and soil displacement techniques can often no longer be utilised due to environmental issues and post-construction maintenance expenses. Stone columns are one method of ground improvement having a proven record of experience which ideally suited for improving soft clays and silts and also for loose silty sands. Apparently, the concept was first applied in France in 1830 to improve a native soil $[1,2]$. It has been used successfully since the 1950's as a technique for improving both cohesive soils and silty sands in United States, Canada, Europe and Asia. The stone columns act as a reinforcing material increasing the overall strength and stiffness of the compressible soft soil. Moreover, the stone columns are highly permeable which is useful in facilitating consolidation process in soft soil improvement program.

In Malaysia, this method has been successfully done especially in highway project. For example, the second phase of the East Coast Expressway between Kuantan and Kuala Terengganu system subjected to extensive soft clay soil with very high water content and undrained shear strengths in the range of 8 to $11 \mathrm{kPa}$ to depths of up to $8 \mathrm{~m}$ required the innovative solution to sup-port an embankment height of up to $12 \mathrm{~m}$. Therefore, vibro-replacement treatment was carried out to improve the soft soil layer [3].

The development of the Boulevard in Putrajaya (1999), the new administrative capital of Malaysia required the construction of 18 $\mathrm{m}$ height earth embankments. The existence of very soft organic clays to a depth of $8 \mathrm{~m}$ to $12 \mathrm{~m}$ with shear strengths in the range of $5 \mathrm{kPa}$ to $7 \mathrm{kPa}$ and $10 \%$ to $20 \%$ organic content caused a problems of slope stability to the proposed embankment. Therefore, ground improvement using vibro-replacement was chosen as an economical and environmentally friendly alternative to the excavation and replacement method. Stone columns were installed to hard impermeable layers to improve the poor shear strength and thereby achieving acceptable factor of safety against slope failure. Typical cross-section of the embankment with stone column treatment is shown in Figure 1.

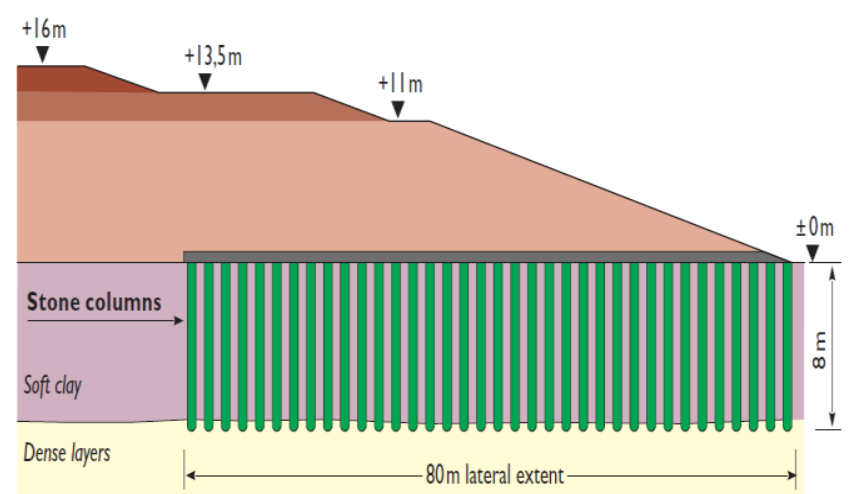

Fig. 1: Typical cross-section of the embankment in Boulevard in Putrajaya, Malaysia [1]

Table 1 tabulates the summary of developed projects in Malaysia using stone column as soft soil improvement method. 
Table 1: Summary of projects utilised stone column method in Malaysia

\begin{tabular}{|c|c|c|}
\hline Project (Year) & $\begin{array}{l}\text { Infrastructure in- } \\
\text { volved }\end{array}$ & Subsoil condition \\
\hline $\begin{array}{lr}\text { KLIA } & \text { Perimeter } \\
\text { Road, } \quad \text { Sepang, } \\
\text { Malaysia } \\
(1996-1997)\end{array}$ & $\begin{array}{l}7.5 \mathrm{~m} \text { height of bridge } \\
\text { abutments }\end{array}$ & $\begin{array}{l}8 \mathrm{~m} \text { to } 10 \mathrm{~m} \text { depth of soft } \\
\text { layer (in one case up to a } \\
22 \mathrm{~m} \text { depth) }\end{array}$ \\
\hline 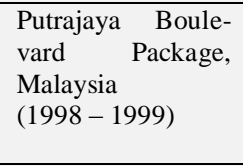 & $\begin{array}{l}\text { Stability against slope } \\
\text { failure in earth em- } \\
\text { bankments. }\end{array}$ & $\begin{array}{l}8 \mathrm{~m} \text { to } 12 \mathrm{~m} \text { depth of soft } \\
\text { organic clay layer with } \\
\text { shear strengths } 5 \text { to } 7 \mathrm{kPa} \\
\text { and } 10 \% \text { to } 20 \% \text { organic } \\
\text { contents. }\end{array}$ \\
\hline $\begin{array}{l}\text { Shah Alam Ex- } \\
\text { pressway (Package } \\
\text { A \& B), Malaysia } \\
(1994-1997)\end{array}$ & $\begin{array}{l}\text { To support an em- } \\
\text { bankment/reinforced } \\
\text { earth (RE) walls with } \\
\text { heights up to } 10 \mathrm{~m}\end{array}$ & $\begin{array}{l}\text { Package A: Alluvium } \\
\text { interspersed with tin } \\
\text { mine tailing deposits } \\
\text { which includes loose } \\
\text { sands and ultra-soft } \\
\text { slimes (undrained shear } \\
\text { strength as low as 6kPa). } \\
\text { Package B: Quaternary } \\
\text { marine and continental } \\
\text { deposits of very soft } \\
\text { clays and silts. }\end{array}$ \\
\hline $\begin{array}{l}\text { Putrajaya (Package } \\
\text { R2a), Selangor, } \\
\text { Malaysia (1999) }\end{array}$ & $\begin{array}{l}\text { To support } 186 \mathrm{~m} \text { long, } \\
\text { and } 150 \mathrm{~m} \text { wide earth } \\
\text { embankment with } 20 \mathrm{~m} \\
\text { and } 24 \mathrm{~m} \text { height. }\end{array}$ & $\begin{array}{l}\text { Very soft clayey silts } \\
\text { having undrained shear } \\
\text { strength of } 7 \mathrm{kPa} \text { at top } \\
4 \mathrm{~m} \text { and } 12 \mathrm{kPa} \text { between } \\
4 \mathrm{~m} \text { and } 8 \mathrm{~m} \text {, followed by } \\
\text { loose to medium dense } \\
\text { sandy layers. }\end{array}$ \\
\hline $\begin{array}{l}\text { Jelutong Express- } \\
\text { way (Stage 1), } \\
\text { Malaysia } \\
(2000-2001)\end{array}$ & $\begin{array}{l}4 \mathrm{~m} \text { and } 7 \mathrm{~m} \text { height of } \\
\text { embankment }\end{array}$ & $\begin{array}{l}6 \mathrm{~m} \text { rubbish heap fol- } \\
\text { lowed by } 10 \mathrm{~m} \text { to } 14 \mathrm{~m} \\
\text { depth of soft marine } \\
\text { clay, underlain by me- } \\
\text { dium stiff to stiff clayey } \\
\text { layers. }\end{array}$ \\
\hline $\begin{array}{l}\text { Putrajaya - Bridge } \\
\text { BR 8, Selangor, } \\
\text { Malaysia (1999) }\end{array}$ & $\begin{array}{l}\text { To support } 4 \mathrm{~m} \text { high } \\
\text { earth embankment and } \\
\text { bridge abutments }\end{array}$ & $\begin{array}{l}\text { Alluvium consists a soft } \\
\text { clayey silts layers } \\
\text { (undrained shear } \\
\text { strength of } 7 \mathrm{kPa} \text { to } \\
\text { 20kPa) with intermittent } \\
\text { loose sandy layers with }\end{array}$ \\
\hline $\begin{array}{l}\text { Guthrie } \\
\text { Overpass, } \\
\text { Kuala Lumpur, } \\
\text { Malaysia (1996) }\end{array}$ & $\begin{array}{l}\text { To support earth em- } \\
\text { bankment and bridge } \\
\text { abutments }\end{array}$ & $\begin{array}{l}2 \mathrm{~m} \text { of earth fill followed } \\
\text { by } 7 \mathrm{~m} \text { depth of soft } \\
\text { clayey silt layers, under- } \\
\text { lain by medium stiff to } \\
\text { stiff cohesive layers }\end{array}$ \\
\hline $\begin{array}{l}\text { Projek Gerbang } \\
\text { Selatan Bersepadu, } \\
\text { Johor Bahru, Ma- } \\
\text { laysia (2003) }\end{array}$ & $\begin{array}{l}\text { Offshore Bridge Abut- } \\
\text { ments }\end{array}$ & $\begin{array}{l}\text { The subsoil below sea- } \\
\text { bed level consists of } 4 \mathrm{~m} \\
\text { to } 7 \mathrm{~m} \text { thickness soft } \\
\text { clay, underlain by bed- } \\
\text { rock }\end{array}$ \\
\hline $\begin{array}{lr}\text { Petronas } & \text { Kedah } \\
\text { Fertilizer r Plant } \\
\text { Line, Gurun, Ma- } \\
\text { laysia (1997) [2] } \\
\end{array}$ & Railway embankment & $\begin{array}{l}\text { Up to } 9 \mathrm{~m} \text { depth of very } \\
\text { soft clayey silts with } \\
\text { SPT N value } 0 \text { to } 2\end{array}$ \\
\hline $\begin{array}{l}\text { Kerteh - Kuantan } \\
\text { Railway Project, } \\
\text { Malaysia }(2000- \\
\text { 2001) }\end{array}$ & Railway embankment & $\begin{array}{l}8 \mathrm{~m} \text { to } 14 \mathrm{~m} \text { depth of soft } \\
\text { cohesive and organic } \\
\text { silts and clays (SPT N = } \\
0, \text { CPT Qc }=200 \text { to } \\
300 \mathrm{kPa})\end{array}$ \\
\hline $\begin{array}{ll}\text { Ipoh } & \text { Rawang } \\
\text { Electrified } & \text { Double } \\
\text { Track } & \text { Project, } \\
\text { Malaysia } & \\
(2001-2004)\end{array}$ & Railway embankment & $\begin{array}{l}\text { Soils are highly variable } \\
\text { mixtures of loose sands } \\
\text { and very soft silts and } \\
\text { clays to depths } 6 \mathrm{~m} \text { to } \\
24 \mathrm{~m} \text {. The soil conditions } \\
\text { have been largely influ- } \\
\text { enced by tin mining } \\
\text { activity in the past. }\end{array}$ \\
\hline $\begin{array}{l}\text { Alor Setar, Malay- } \\
\text { sia (2003-2004) }\end{array}$ & $\begin{array}{l}\text { Airport Runways, turn- } \\
\text { pad and Taxiways }\end{array}$ & $\begin{array}{l}8 \mathrm{~m} \text { to } 12 \mathrm{~m} \text { depth of very } \\
\text { soft to soft silty clay } \\
\text { layers with intermittent } \\
\text { sandy layers. }\end{array}$ \\
\hline $\begin{array}{l}\text { New Pantai High- } \\
\text { way }(2001-2003)\end{array}$ & $\begin{array}{l}\text { To support highway } \\
\text { embankments } \text { and } \\
\text { reinforced earth (RE) }\end{array}$ & $\begin{array}{l}\text { Different types of soils } \\
\text { at different locations } \\
\text { include loose silty sands, }\end{array}$ \\
\hline
\end{tabular}

\begin{tabular}{|l|l|l|}
\hline & walls & $\begin{array}{l}\text { soft clays and soft min- } \\
\text { ing slimes to depths of } \\
6 \mathrm{~m}, 15 \mathrm{~m} \text { and } 18 \mathrm{~m}, \text { re- } \\
\text { spectively }\end{array}$ \\
\hline
\end{tabular}

Usually, column filler materials comprise of aggregate stones generally between $20 \mathrm{~mm}$ to $75 \mathrm{~mm}$, are compacted to vertical holes normally 0.6 meters to 1.0 meters in diameter and depths of 15 meters to 20 meters. Many studies have been conducted relating to the effectiveness of stone column as soft soil improvement, along with the effect of encasement and un-encasement over the stone column using aggregates stone material. However, the impact on environment and sustainability matters also need to be concerned in term of suitable material selection for replacement. Light weigh expanded clay aggregate (LECA) are among the common lightweight materials that have been applied successfully in geotechnical application. It can reduce the weight of compacted geotechnical fills by up to one and a half. This material is currently being used in many civil engineering works due to its low weight, high strength and favourable drainage characteristics. In terms of their dimensions, the LECA particles can be classified as gravels. Previous study shows that the LECA has been used as filler material for road embankment construction and filling behind retaining wall, airport pavement subgrades, planting and storm water drainage system [6]. However no researchers have been made to explore the effectiveness of stone columns using Lightweight Expanded Clay Aggregate (LECA) as filler material [7]. This paper will discuss on the effectiveness of using LECA materials as a replacement of a normal aggregates as a filler for stone column construction.

\section{Stone Columns}

Stone columns are an effective ground treatment technique which is used over the decades to reduce settlement and in-crease bearing capacity of the soft soil foundations. Initially, the method to calculate the settlement of stone columns was first presented by Greenwood (1970) where a chart of this purpose was developed based on experimental work [8]. Hughes and Withers (1974) [1] observed that a single stone column bulges as the result of applying load and collapse due to bulging failure and summarized that group of stone columns can have the same collapse form. In 1976, Priebe developed a theoretical model based on settlement of single stone column [9] which is assumed that the deform behaviour of stone columns group is same as the single one and developed the theory for single stone column by considering that it can be applied to group of columns as well. Later Balaam and Booker (1981), Goughnour and Bayuk (1979), Barksdale and Bachus (1983), Poorooshasb and Meyerhof (1997) and Poorooshasb et al. (1997) developed theoretical and numerical models based on the same assumption first suggested by Hughes and Withers [2,10-12] Lee and Pan-de (1998) then developed a method based on homogenization approximation where it was assumed that granular material scattered homogenously throughout the soil and finite element code was written to solve the problem [13]. In $1995 \mathrm{Hu}$ [14] criticized the assumption made by Hughes and Withers (1974) and others and declared that group of stone columns perform a deformed shape as the result of loading which is quite different from single columns. Hu also concluded that the group of stone columns failed due to shear. The same observation also has been reported by Wehr W. (1999), Wood et al. (2000), Seok Bae and Shin (2002) and Etezad et al. (2007) [13,15-17] [9,12]. Hanna A. et al. (2016) developed new procedure to estimate settlement of the ground reinforced with group of stone columns which overcomes the limitations made by previous theories through numerical modelling.

Most of the literature reviews have shown the convenient of reporting the performance of stone column using settlement improvement factor, $\mathrm{n}$ (ratio of settlement of untreated ground over 
settlement of treated ground) or settlement reduction ratio, $1 / \mathrm{n}$ in almost all stone columns studies or case histories. The prediction of the settlement reduction due to the primary consolidation of stone column to reinforced grounds employed the end-bearing type of columns, where the most popular one is semi-empirical method proposed by Priebe (1995). This method is based on the unit cell concept and the columns are considered to be in a plastic state, while the surrounding soil behaves elastically. Meanwhile, the settlement of floating columns was calculated using conventional method, where the settlement of improved and unimproved layers was computed separately, referred to as a two-layer system approach as proposed by Rao and Ranjan (1985), Japan Institute of Construction Engineering (JICE) (1999) and $\alpha-\beta$ method suggested by Chai et al. (2009). The settlement performance prediction of floating stone columns for the infinite grid column type was established by $\mathrm{Ng}$ and Tan (2014) [3].

\subsection{Performance of LECA Columns}

The Finite Element (FE) results are presented in terms of settlement ratio $\left(S / S_{u c}\right.$, where $S$ is the settlement of floating column group and $S_{u c}$ is the settlement of end bearing column in the unit cell model). This relationship has been proposed by Kok Shien $\mathrm{Ng}$ (2017) [4]. The performance of floating stone columns either for large or small groups can be predicted using the results of large group end bearing type columns. The simple method for obtaining the settlement improvement factor for the end bearing columns under infinite grid condition (valid for $\alpha=0.1$ to 0.45 ) has been proposed by Ng and Tan (2014) [20]. Design chart to estimate the performance of floating stone column for small and large columns group was developed by $\mathrm{Ng}$ (2017) [19]. This simplified solution was established based on the influence of key parameters such as column length, area replacement ratio, loading intensity and post installation lateral earth pressure and will be used as comparison in this study. The same method will be used to evaluate the LECA column performance in this study. However, the influence of depth ratio and area replacement ratio were focused in the analysis. According to $\mathrm{Ng}$ (2017), area replacement ratio is the most important variable in floating stone columns design other than the length of columns. Figure 1 represents the influence of area replacement ratio on settlement ratio. By careful selection of these two variables, a design engineer can provide optimum design for the stone column improved ground using Equation (1), where $\alpha$ is area replacement ratio and $\beta$ is depth ratio.

$\frac{s}{s_{u c}}=1+7.9 \alpha^{14}(1-\beta)$

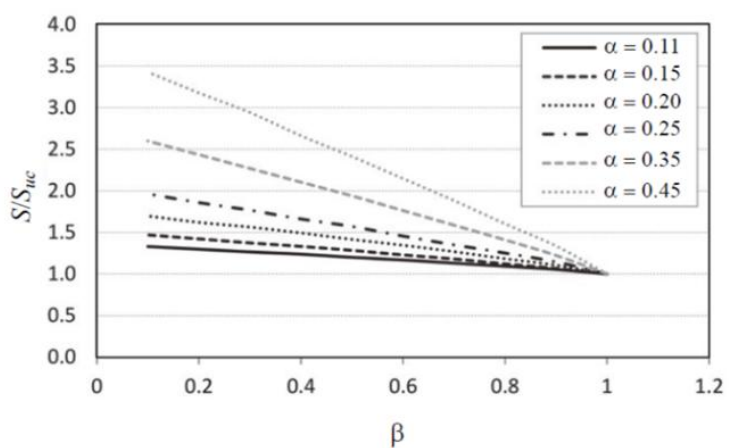

Fig. 1: Influence of area replacement ratio on settlement ratio

\section{Numerical Modelling: Procedures and Dis- cussions}

In order to calculate final settlement of the ground reinforced with group of LECA columns, numerical model was developed using Plaxis 3D (2016). To permit timely analysis in this research and to simulate long term soil behaviour, drained analysis is adopted to allow more sensitivity and parametric analysis to be performed. Square arrangement of stone columns was considered in this study and fine form of mesh generation was utilized as the global coarseness of the model. Mohr-Coulomb constitutive law was used for LECA granular material while Soft Soil Hardening model was adopted to represent the behaviour of soft soil in this study. LECA columns are assumed to be 'wish in place', where possible smear effects caused by disturbance on the surrounding soil due to column installation effect is neglected. A vertical pressure of 50 $\mathrm{kN} / \mathrm{m}^{2}$ is imposed as a distributed load over the entire surface area of the surface where rigid plate is assigned as a medium for load transfer to the above ground. Geometrical detail of LECA column is shows in Figure 2. Table 2 illustrates the LECA, soft soil and geometry properties which were used in the numerical model.

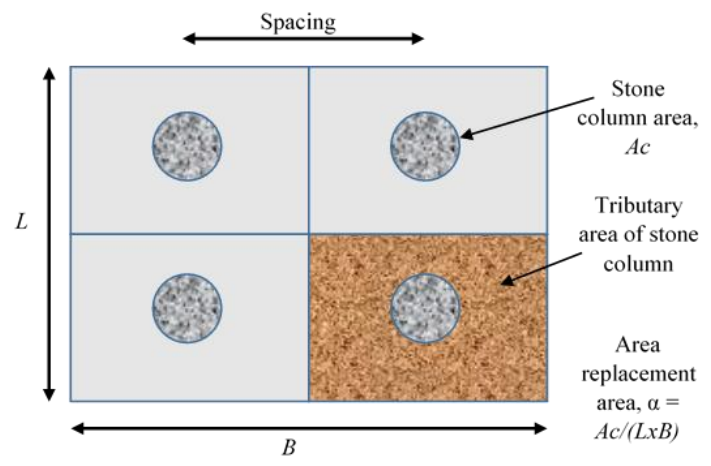

Fig. 2: Geometrical detail of LECA column

Table 2: Materials properties used in modelling

\begin{tabular}{|c|c|c|}
\hline Materials & Site conditions & Range of values \\
\hline Clay & $\begin{array}{c}\text { Constitutive Model } \\
\text { Type of analysis } \\
\text { Unit weight, } \gamma\left(\mathrm{kN} / \mathrm{m}^{3}\right) \\
\text { Young's Modulus, } \mathrm{E}\left(\mathrm{kN} / \mathrm{m}^{2}\right) \\
\text { Cohesion, c' }\left(\mathrm{kN} / \mathrm{m}^{2}\right) \\
\text { Friction angle, } \varphi^{\prime}\left(^{\circ}\right) \\
\text { Dilatation angle, } \Psi^{\prime}\left(^{\circ}\right) \\
\text { Poisson's ratio, } v \\
\text { Permeability, } \mathrm{k}(\mathrm{m} / \mathrm{s}) \\
\text { Undrained shear strength } \\
\left(\mathrm{kN} / \mathrm{m}^{2}\right) \\
\mathrm{Cc} \\
\mathrm{Cr} \\
\mathrm{e}_{0}\end{array}$ & $\begin{array}{c}\text { SHM } \\
\text { Drained } \\
16 \\
2420 \\
7 \\
25^{\circ} \\
0 \\
0.30 \\
2.58 \times 10-10 \\
7.5 \\
0.256 \\
0.058 \\
2.39\end{array}$ \\
\hline LECA & $\begin{array}{c}\text { Constitutive Model } \\
\text { Type of analysis } \\
\text { Unit weight, } \square\left(\mathrm{kN} / \mathrm{m}^{3}\right) \\
\text { Young's Modulus, } \mathrm{E}\left(\mathrm{kN} / \mathrm{m}^{2}\right) \\
\text { Cohesion, c' }(\mathrm{kN} / \mathrm{m} 2) \\
\text { Friction angle, } \varphi^{\prime}\left(^{\circ}\right) \\
\text { Dilatation angle, } \Psi^{\prime}\left(^{\circ}\right) \\
\text { Poisson's ratio, } v \\
\text { Permeability, } \mathrm{k}(\mathrm{m} / \mathrm{s})\end{array}$ & $\begin{array}{c}\mathrm{MC} \\
\text { Drained } \\
3,5,7,9 \\
2520 \\
0 \\
35^{\circ} \\
5 \\
0.30 \\
2.53 \times 10^{-2}\end{array}$ \\
\hline $\begin{array}{l}\text { Geometry } \\
\text { condition }\end{array}$ & $\begin{array}{c}\text { LECA column Diameter, D } \\
\text { Area replacement ratio, } \alpha \\
\text { Ratio of } \mathrm{L} / \mathrm{D}\end{array}$ & $\begin{array}{c}0.7 \text { meter } \\
10 \%, 20 \%, 30 \%, \\
40 \% \\
3,5,6,7,8 \text { and End } \\
\text { bearing }\end{array}$ \\
\hline
\end{tabular}

The analysis has been performed on LECA column installed in the middle of the group which is constraint by the other columns. Columns within the group are restrained equally on all sides and held in the same vertical stress conditions. However, at the edge of wide load areas columns are not generally re-strained by other columns and must depend on the surrounding soil to provide restraint in the outward facing directions [21]. This behaviour is more complex due to the lack of restraint with columns subject to deformation at lower stress levels than those in infinite arrays. Hence, column at the edge of the group was not analysed due to this complexity. Methodology flowchart is shows in Figure 3. 


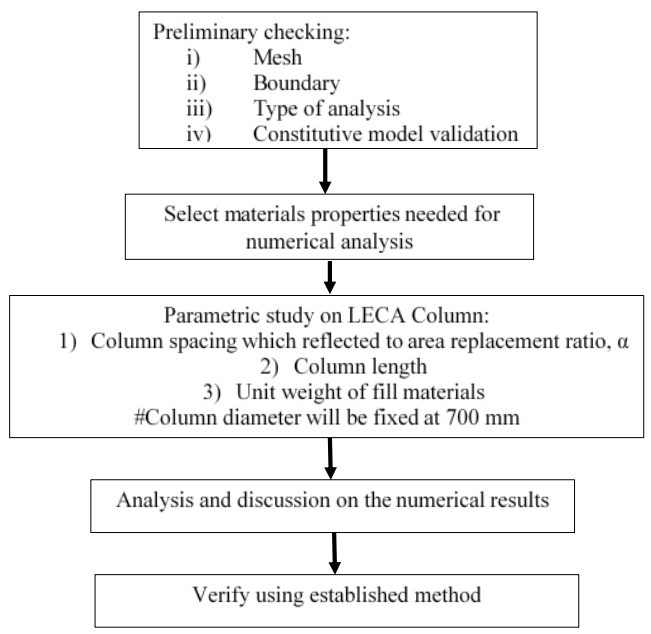

Fig. 3: Methodology flowchart

\section{Results and Analysis}

Figure 4A to Figure 4D below represent the plot of settlement ratio against depth ratio for floating LECA column with respective unit weight of LECA. $\beta$ is the depth ratio (the ratio of LECA column length to depth of soft soil).

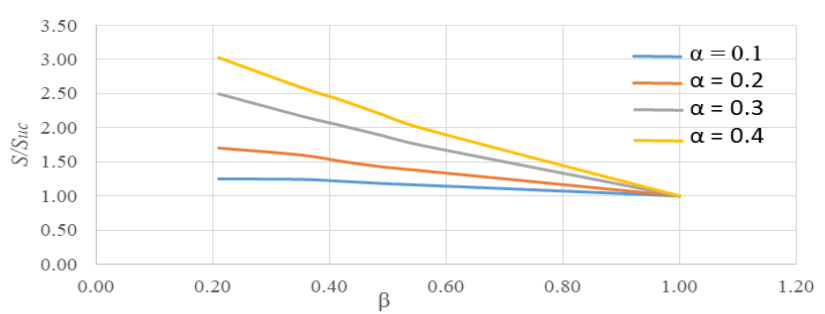

Fig. 4A: Influence of area replacement ratio on settlement ratio (LECA 3)

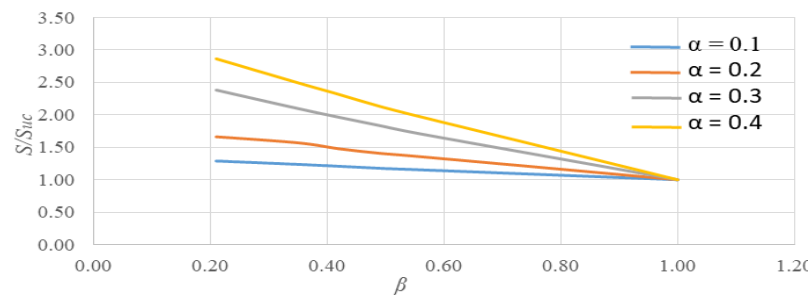

Fig. 4B: Influence of area replacement ratio on settlement ratio (LECA 5)

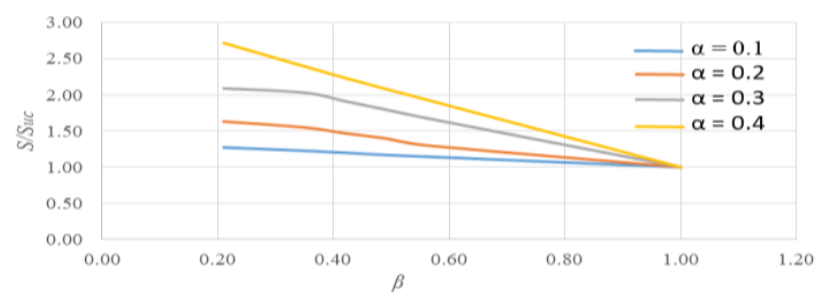

Fig. 4C: Influence of area replacement ratio on settlement ratio (LECA 7)

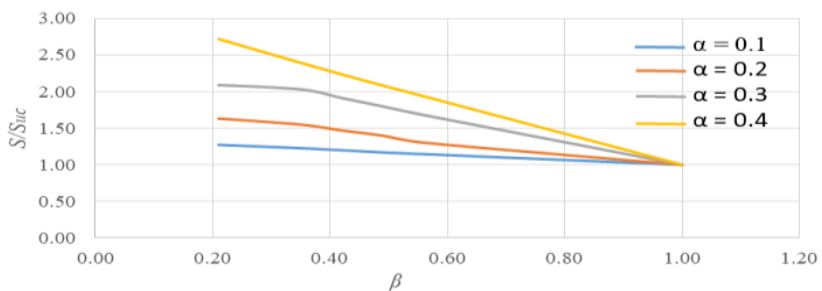

Fig. 4D: Influence of area replacement ratio on settlement ratio (LECA 9)
The settlement ratio reduces as the column length increases until unity at end bearing condition where $\beta=1.0$. Higher area replacement ratio results in a higher settlement ratio. The plot pattern is similar to study conducted by $\mathrm{Ng}$ (2017) for all unit weight of LECA. From the analysis, the highest settlement ratio is near to 3 for $\alpha=0.4$ in LECA 3 and LECA 5 which means about 3 times the settlement of floating LECA column compared to the end bearing LECA columns. This ratio was close to the value obtained in the previous study, even though different filler materials were used in the column. In addition to that, Figure 3 illustrates the plot of settlement ratio against length to diameter ratio (L/D) for various unit weight of LECA. The plot shows that higher L/D ratio and closer spacing of LECA columns provide lower settlement ratio.

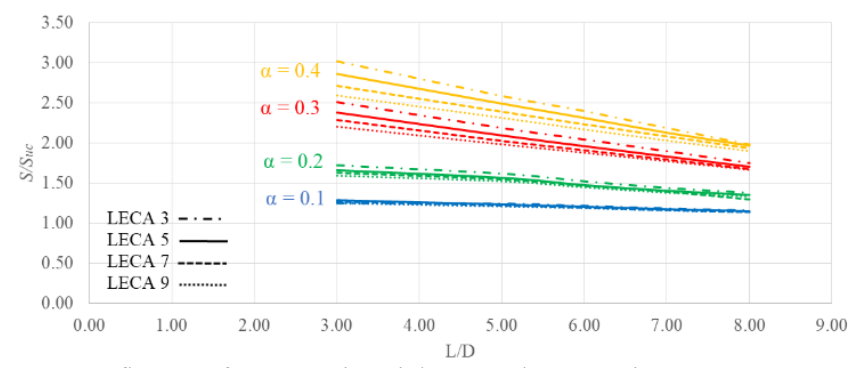

Fig. 5: Influence of LECA unit weight on settlement ratio, $\alpha$

The settlement ratio obtained for LECA 7 and LECA 9 only decreased slightly (2.5 to 3.0) indicating the unit weight of the material did not affect the value of the settlement ratio. The following plots in Figure 6A to 6D prove the unit weight of the material is not the main important factor affecting the settlement ratio.

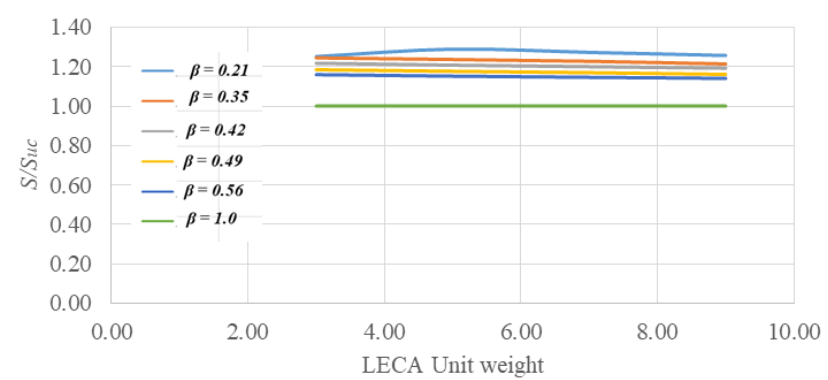

Fig. 6A: Influence of LECA unit weight on settlement ratio $(\alpha=0.1)$

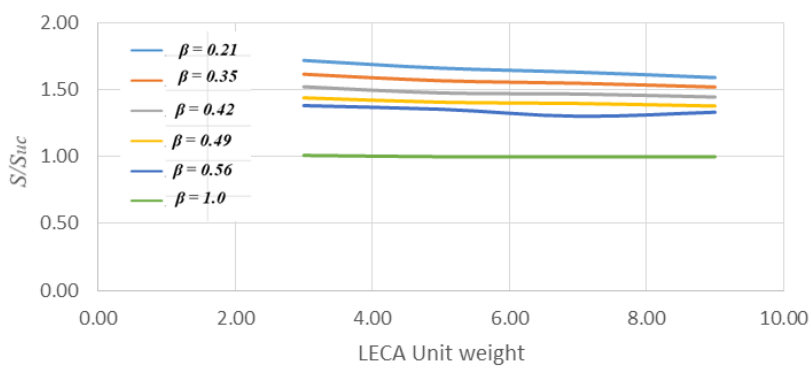

Fig. 6B: Influence of LECA unit weight on settlement ratio $(\alpha=0.2)$

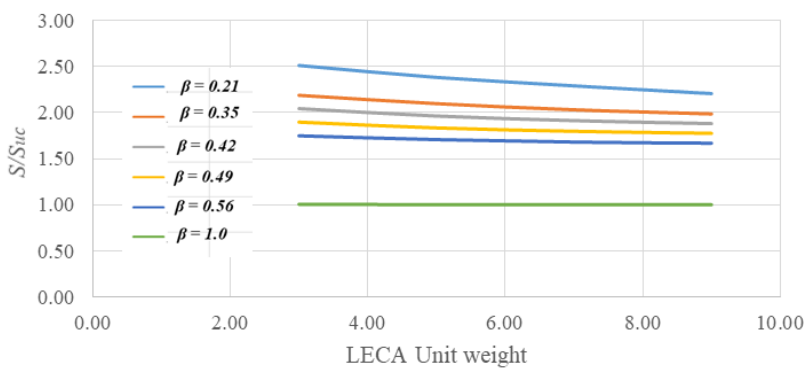

Fig. 6C: Influence of LECA unit weight on settlement ratio $(\alpha=0.3)$ 


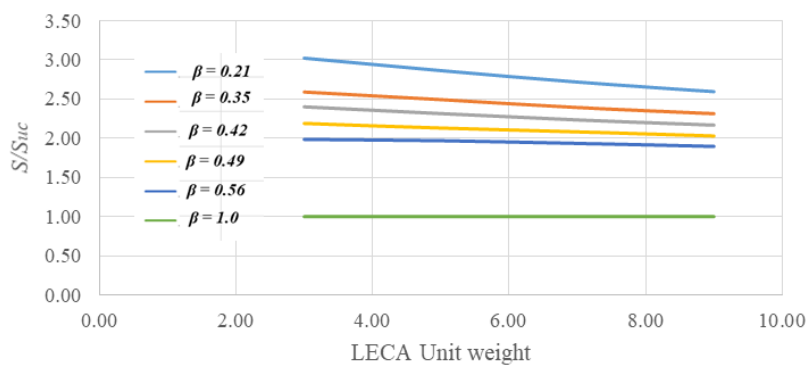

Fig. 6D: Influence of LECA unit weight on settlement ratio $(\alpha=0.4)$

\subsection{Verification Using Analytical Method Established}

The prediction of settlement performance through FE modelling in this study was compared with equation developed by $\mathrm{Ng}$ (2017). The comparison results in terms of the settlement ratio for $\alpha=0.1$, $0.2,0.3$ and 0.4 are shown in Figure 7A to 7D. The findings were in good agreement with Ng's method, (2017) where the error was less than $15 \%$. It shows that, the performance of LECA columns have been successfully predicted using this equation even though the method developed for settlement performance prediction of stone column with normal granular materials.

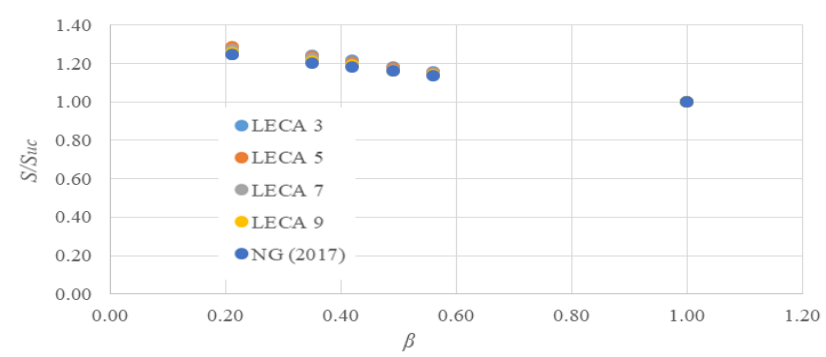

Fig. 7A: Comparison results for settlement ratio at $\alpha=0.1$

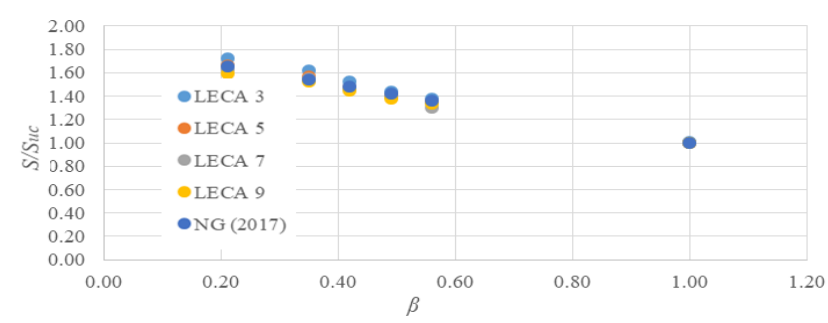

Fig. 7B: Comparison results for settlement ratio at $\alpha=0.2$

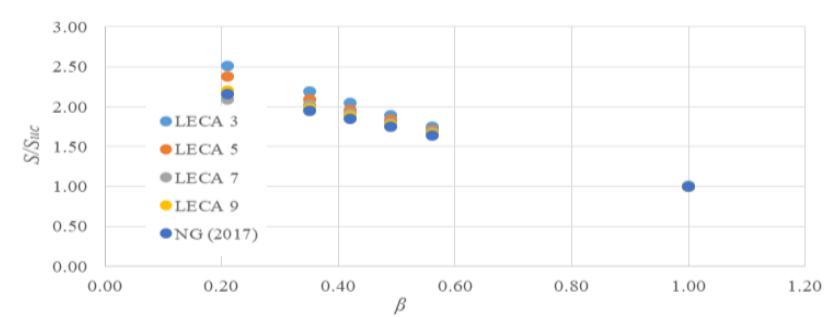

Fig. 7C: Comparison results for settlement ratio at $\alpha=0.3$

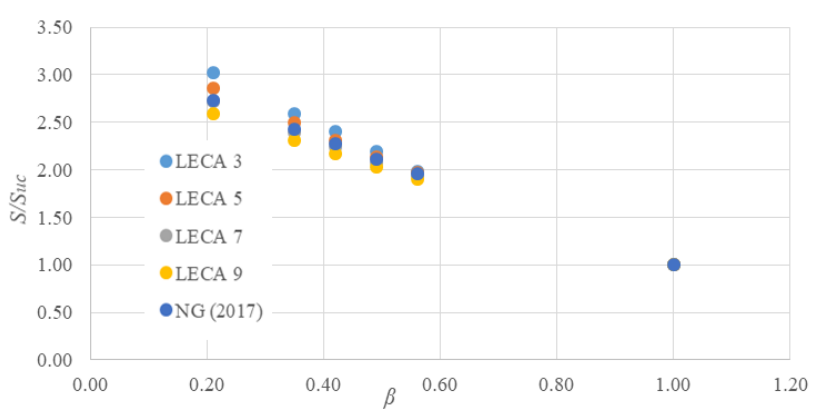

Fig. 7D: Comparison results for settlement ratio at $\alpha=0.4$
The comparison of numerical analysis in this study also has been made with the analytical solution that has been established before as presented in Figure 8 below. The differences in the settlement improvement factors, $\eta$ obtained by different methods are quite significant especially when compared with Ng's method (2014) [5], while the settlement improvement factor is quite similar when the Priebe's method [6] is used. However, the general trend of the results is found to be similar.

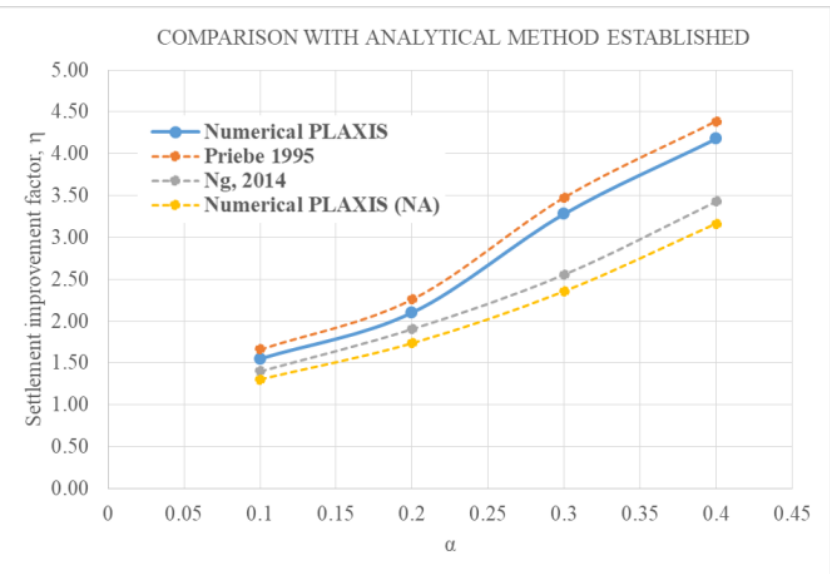

Fig. 8: Comparison FE results with other analytical methods

\subsection{Bulging Failure in LECA Columns}

Lateral or bulging failure is the common problem of unencasement stone column installed in soft cohesive soil causes excessive settlements. Bulging is the main reason that influence the failure in stone column. Generally it is happens within the top portion of 2 to 3 times the diameter of column [7]. However, study conducted by Pitt et al. (2003) and Murugesan and Rajagopal (2006) through numerical and experimental methods indicated that even bulging can occur in shallower depth less than 2 to 3D $[8,9]$. To avoid this issue, the column spacing can be reduced, increase the column diameter or length, or by excavation to bypass the soft layers. McKelvey et al. (2004) carried out experimental studies on a group of five stone columns and reported that the central column deformed or bulged uniformly, while the edge columns bulged away from the neighbouring columns [10]. While, bending failure is predominant in 'perimeter' columns located beyond the centre of the footing.

Figure 9 illustrates the bulging failure on stone columns group. Y. Srilekha and S. Nirisha (2016) performed a study on bulging failure of stone columns with varying Length to Diameter (L/D) ratio and concluded that the $\mathrm{L} / \mathrm{D}$ ratio was the main factor that influenced the bulging failure [11].

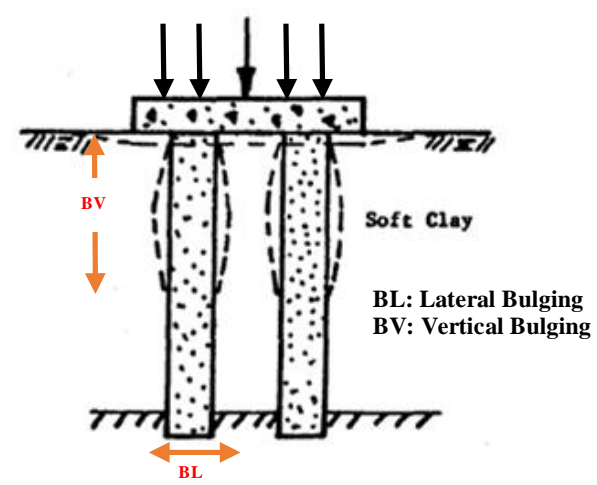

Fig. 9: Bulging failure on small columns group

Table 3 illustrates the lateral (BL) and vertical (BV) extent of bulging of LECA column. From Table 2, bulging happened within 
2 to $3 \mathrm{D}$ in LECA column with $\alpha=0.1$, while in $\alpha=0.2,0.3$ and 0.4 , bulging occurred within 4 to $7 \mathrm{D}$. The results shows that the vertical extent of bulging (BV) is predominantly influenced by $\mathrm{L} / \mathrm{D}$ ratio. However, lateral bulging (BL) was not influenced by $\mathrm{L} / \mathrm{D}$ ratio. This findings is in good aggreement with previous study conducted by Y. Srilekha and S. Nirisha (2016). This means that, the bulging behaviour in LECA column is the same as conventional stone column even though different filler materials used. Bulging failure for various area replacement ratios are presented in Figure 10.

Table 3: Lateral (BL) and vertical (BV) extent of bulging of stone column

\begin{tabular}{|c|c|c|c|c|c|c|c|c|c|c|}
\hline & & & & $\mathrm{s} \mathrm{st}$ & & & & & Y. Sr & \\
\hline$\alpha$ & & & & & & & & & $\begin{array}{l}\text { S } \\
(20\end{array}$ & \\
\hline $\begin{array}{l}\mathrm{L} / \\
\mathrm{D}\end{array}$ & BL & $\begin{array}{l}\text { B } \\
\text { V }\end{array}$ & BL & $\begin{array}{l}\text { B } \\
V\end{array}$ & BL & $\begin{array}{l}\mathrm{B} \\
\mathrm{V}\end{array}$ & BL & $\begin{array}{l}\text { B } \\
V\end{array}$ & BL & BV \\
\hline 3 & $\begin{array}{l}1.5 \\
\mathrm{D}\end{array}$ & $\begin{array}{l}2 \\
D\end{array}$ & $\begin{array}{c}1.4 \\
\text { D }\end{array}$ & $\begin{array}{l}2 \\
D\end{array}$ & $\begin{array}{c}1.4 \\
\text { D }\end{array}$ & $\begin{array}{l}2 \\
D\end{array}$ & $\begin{array}{l}1.3 \\
\text { D }\end{array}$ & $\begin{array}{l}2 \\
D\end{array}$ & 1.6D & $\begin{array}{c}2.5 \\
D\end{array}$ \\
\hline 4 & - & - & - & - & - & - & - & - & $1.5 \mathrm{D}$ & $3 \mathrm{D}$ \\
\hline 5 & $\begin{array}{c}1.4 \\
D\end{array}$ & $\begin{array}{l}3 \\
D\end{array}$ & $\begin{array}{c}1.7 \\
\mathrm{D}\end{array}$ & $\begin{array}{l}3 \\
\mathrm{D}\end{array}$ & $\begin{array}{c}1.4 \\
\mathrm{D}\end{array}$ & $\begin{array}{l}4 \\
\mathrm{D}\end{array}$ & $\begin{array}{c}1.3 \\
\mathrm{D}\end{array}$ & $\begin{array}{l}4 \\
\mathrm{D}\end{array}$ & & 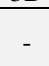 \\
\hline 6 & $\begin{array}{c}1.5 \\
D\end{array}$ & $\begin{array}{l}2 \\
D\end{array}$ & $\begin{array}{c}1.7 \\
D\end{array}$ & $\begin{array}{l}5 \\
D\end{array}$ & $\begin{array}{c}1.4 \\
\mathrm{D}\end{array}$ & $\begin{array}{l}5 \\
D\end{array}$ & $\begin{array}{c}1.3 \\
D\end{array}$ & $\begin{array}{l}5 \\
D\end{array}$ & $\begin{array}{c}1.65 \\
\text { D }\end{array}$ & $\begin{array}{c}5.5 \\
D\end{array}$ \\
\hline 7 & $\begin{array}{c}1.5 \\
D\end{array}$ & $\begin{array}{l}2 \\
D\end{array}$ & $\begin{array}{c}1.8 \\
\text { D }\end{array}$ & $\begin{array}{l}6 \\
D\end{array}$ & $\begin{array}{c}1.4 \\
\text { D }\end{array}$ & $\begin{array}{l}5 \\
\mathrm{D}\end{array}$ & $\begin{array}{c}1.3 \\
\text { D }\end{array}$ & $\begin{array}{l}4 \\
\mathrm{D}\end{array}$ & - & - \\
\hline 8 & $\begin{array}{l}1.5 \\
D\end{array}$ & $\begin{array}{l}3 \\
\mathrm{D}\end{array}$ & $\begin{array}{c}1.7 \\
\mathrm{D}\end{array}$ & $\begin{array}{l}7 \\
\text { D }\end{array}$ & $\begin{array}{c}1.5 \\
D\end{array}$ & $\begin{array}{l}7 \\
\mathrm{D}\end{array}$ & $\begin{array}{c}1.3 \\
\mathrm{D}\end{array}$ & $\begin{array}{l}5 \\
\mathrm{D}\end{array}$ & $\begin{array}{c}1.65 \\
D\end{array}$ & $5 \mathrm{D}$ \\
\hline 10 & - & - & - & - & - & - & - & - & $1.6 \mathrm{D}$ & 7D \\
\hline 14 & $\begin{array}{c}1.5 \\
D\end{array}$ & $\begin{array}{l}2 \\
\mathrm{D}\end{array}$ & $\begin{array}{c}1.5 \\
D\end{array}$ & $\begin{array}{l}2 \\
D\end{array}$ & $\begin{array}{c}1.4 \\
\text { D }\end{array}$ & $\begin{array}{l}7 \\
\mathrm{D}\end{array}$ & $\begin{array}{c}1.3 \\
\text { D }\end{array}$ & $\begin{array}{l}5 \\
\mathrm{D}\end{array}$ & - & - \\
\hline
\end{tabular}

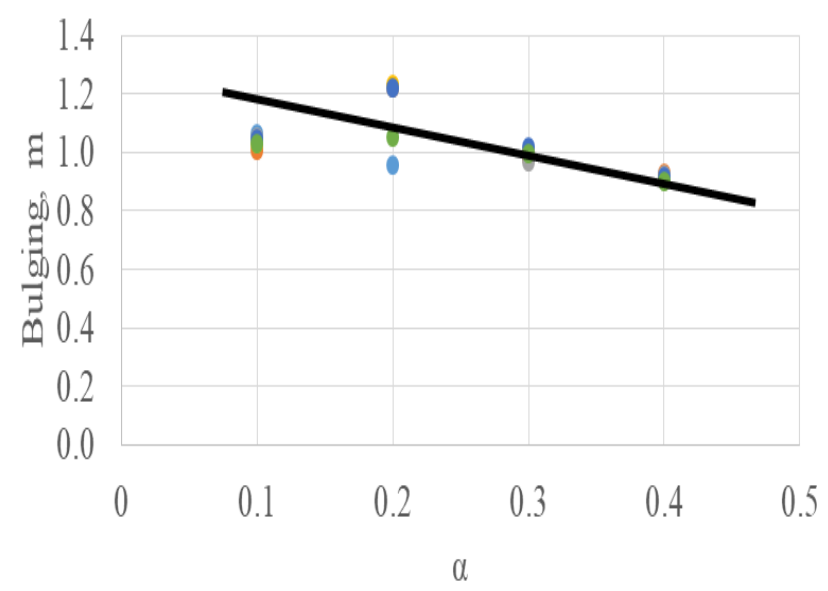

Fig. 10: Bulging failure for varies area replacement area

It is observed that bulging was reduced with increasing of area replacement ratio or closer spacing between LECA columns. This finding was in good agreement with previous studies conducted on conventional stone columns.

\section{Conclusion}

The study proves that Lightweight Expanded Clay Aggregate (LECA) is suitable material to substitute normal aggregate, sand, and other granular materials as column filler in ground improvement work. Numerical analysis was performed to examine the settlement of treated soft clay by LECA columns in 3D models under drained condition. A few conclusions can be drawn from this study;

1. The settlement ratio reduces as the column length increases until unity at end bearing condition where $\beta=1.0$. Higher area replacement ratio results in a higher settlement ratio, which indicating that closer spacing provide better improvement.
2. The study revealed that the unit weight of the filler material (LECA) is not main important factor affecting the settlement ratio.

3. The performance of LECA columns have been successfully predicted using Ng's equation (2017) even though the method developed for settlement performance prediction of stone column with normal granular materials.

4. It is observed that bulging was reduced with increasing of area replacement ratio or closer spacing between LECA columns.

5. The results show that bulging was happen within 2 to $3 \mathrm{D}$ in LECA column with $\alpha=0.1$, while in $\alpha=0.2,0.3$ and 0.4 , bulging was occurred within 4 to $7 \mathrm{D}$. The vertical extent of bulging (BV) is dominatingly influenced by L/D ratio. However, lateral bulging (BL) was not influenced by L/D ratio.

\section{Acknowledgement}

The authors wish to thank the Universiti Teknologi Malaysia and Universiti Teknologi Mara, Pulau Pinang for providing facilities during the research work.

\section{References}

[1] Hughes J M O W N J 1974 Reinforcing of soft cohesive soils with stone columns Ground Engineering 7 42-9

[2] R. D. Barksdale R C B 1983 Design and Construction of Stone Columns (Washington, DC)

[3] Aljanabi Q A, Chik Z and Kasa A 2013 Construction of a new highway embankment on the soft clay soil treatment by stone columns in Malaysia Journal of Engineering Science and Technology 8 448--456

[4] Raju V R, Wegner R . and Krishna Y H 2004 Ground Improvement using Vibro Replacement in ASIA 1994 to 2004. A 10 year review 5th International Conference on Ground Improvement Techniques

[5] Spears D S 2014 Soil Improvement Using Vibro-Replacement Aquila: The FGCU Student Journal 1 1-5

[6] Holm T A and Valsangkar A J 1993 Lightweight Aggregate Soil mechanics: Properties and Applications (Transportation Research Record)

[7] Zukri A and Nazir R 2018 The Sustainable Materials Used As Stone Column Filler: A Short Review iCITES2018

[8] Greenwood D A 1970 Mechanical Improvement Of Soils Below Ground Surface Ground Engineering Conference, Institution Of Civil Engineers (London: ICE Publishing) pp 11-22

[9] Mohammadreza Jaberi Nasab A A 2015 Numerical Analysis of the Bearing Capacity of Stone Columns Impoved Ground International Journal of integrative Sciences, Innovation and Technology 4 1-5

[10] Hughes Withers N J J M O 1974 Reinforcing of soft cohesive soils with stone columns Ground Engineering 7 42-9

[11] Goughnour R R and Barksdale R D 1984 Performance of a Stone Column Supported Embankment International Conference on Case Histories in Geotechnical Engineering. pp 735-42

[12] N.P.Balaam J R B 1981 Analysis of rigid rafts supported by granular piles International Journal for Numerical and Analytical Methods in Geomechanics 5 379-403.

[13] S L J and N P G 1998 Analysis of stone- column reinforced foundations International Journal for Numerical and Analytical Methods in Geomechanics 22 1001-20

[14] Hu W 1995 Physical modelling of group behaviour of stone column foundations

[15] Wood D M, Hu W and Nash D F T 2000 Group effects in stone column foundations: model tests Géotechnique 50 689-98

[16] Oh E Y N, Huang M, Surarak C, Adamec R and Balasurbamaniam a S 2008 Finite Element Modeling for Piled Raft Foundation in Sand Engineering \& Construction 1-8

[17] Hanna A, Ayadat T, Etezad M and Cros C 2016 Settlement of A Group Of Stone Columns In Soft Soil Science des matériaux (Laboratoire LARHYSS) 7

[18] Ng K S and S.A.Tan 2014 Floating Stone Columns Design and Analyses Soils and Foundations 54 478-487 
[19] Ng K S 2017 Settlement Ratio of Floating Stone Columns for Small And Large Loaded Areas Journal of GeoEngineering 12 8996

[20] Kok Shien Ng S A T 2014 Floating Stone Columns Design and Analyses Soils and Foundations -Tokyo 1-27

[21] Law S 2015 Numerical Modelling of the behaviour of stone and composite stone columns in soft soils (Heriot-Watt University)

[22] Priebe H J 1995 The Design of Vibro Replacement

[23] Han J 2015 Principles and Practice of Ground Improvement (John Wiley \& Sons, Inc. Hoboken, New Jersey)

[24] John M. Pitt, David J. White, Aaron Gaul K H 2003 Highway application for rammed aggregate piles in Iowa soils

[25] Murugesan S and Rajagopal K 2006 Geosynthetic-encased stone columns: Numerical evaluation Geotextiles and Geomembranes 24 349-58

[26] McKelvey D, Sivakumar V, Bell A and Graham J 2004 Modelling vibrated stone columns in soft clay Proceedings of the Institution of Civil Engineers - Geotechnical Engineering 157 137-49

[27] Srilekha Y and Nirisha S 2016 An Experimental Investigation on the Load Settlement and the Bulging Behaviour of Stone Columns Placed on Highly Plastic Clays Indian Journal of Science and Technology 9 